This is the post print version of the article, which has been published in Baltic Journal of Management. 2019, 14 (1), 141-157.https://doi.org/10.1108/ BJM-12-2017-0416

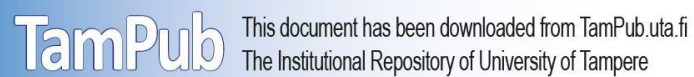

Post-print

Rajala, T. and Laihonen, H. (2018), "Managerial choices in orchestrating dialogic performance management", Special issue "Accounting and performance management innovations in public sector organizations

Corresponding author: tomi.rajala@uta.fi 


\section{Managerial choices in orchestrating dialogic performance management}

\section{Structured Abstract}

Purpose: The aim of this study is to propose a definition for dialogic performance management and investigate the managerial choices that dialogic performance management necessitates from public managers.

Design/Methodology/Approach: The research strategy was based on a narrative analysis grounded in relativism and constructivism. Multiple data collection methods were used in this case study to examine a local government in Finland.

Findings: The article proposes a definition and provides practical illustrations of the concept of dialogic performance management. Our empirical findings are a set of managerial choices used to orchestrate dialogic performance management.

Practical implications: The concept of dialogic performance management encourages practitioners to ask themselves whether their current performance management practices are based on managerial monologues, rather than dialogues that incorporate staff into the performance management. The results also show that managerial choices shape the form of dialogic performance management.

Originality/Value: The previous accounting and performance management literature has not examined the managerial choices that are used to shape dialogic performance management. In this research, we identify these types of managerial choices in our case organization. Our research is valuable because only after explicating managerial choices can one start to examine why dialogic performance management either fails or succeeds when public managers orchestrate it.

Keywords: dialogic performance management, performance dialogue, performance management, performance information, public management 


\section{Introduction}

Performance information in the public sector has been described as uncomprehensive, ambiguous, and subjective (Moynihan, 2008a; Vakkuri, 2010). Interpreting this type of performance information has increased the need for using a performance dialogue, a process in which a group of people discuss the interpretation of performance information and the actions needed to improve performance according to this interpretation (Rajala et al., 2018). The suggestion to use performance dialogues is based upon the notion that these dialogues can help public sector actors better understand and manage the complexity and ambiguity associated with public sector performance (De Bruijn and Van Helden, 2006; Laihonen and Mäntylä, 2017). The underlying assumptions are that performance management can be dialogic and that certain benefits are associated with the dialogue (cf. Moynihan, 2005). For example, dialogue can be utilized to improve practices in which performance is measured and reported in a very narrow way by using costs or other purely monetary measures (Bebbington et al., 2007). However, critics claim that dialogue as a performance management practice may end up enhancing the power of political elites (Celerier and Botey, 2015; Kuruppu et al., 2016) and cause pseudo-participation in attempts to create legitimacy (Uddin et al., 2011). A dialogue may also turn into a monologic procedure based on the way practitioners use it (Baiocchi and Ganuza, 2014; Harun et al. 2016; Aleksandrov et al. 2018).

Although accounting and performance management studies have highlighted the need for dialogue both in the societal and organizational levelMoynihan, 2005; Brown, 2009; Brown and Dillard, 2015a; Brown and Dillard, 2015b), we argue that these studies have not been designed to map out the managerial choices that public managers face when designing and implementing dialogic performance management. Previous research usually describes how conversations turn into dialogues when people change their discussion habits and what successful and unsuccessful dialogues look in terms of participant behavior and the outcomes of the dialogue (cf. Isaacs, 2001a; Bebbington et al., 2007; Moynihan, 2008a). Some studies even present managerial choices that shape dialogues, though their research settings have not been designed to study them (e.g., Moynihan 2008a; Brown 2009; Brown and Dillard, 2015ab; Aleksandrov et al. 2018). However, the previous literature seems to paint an oversimplified picture of the choices relating to these dialogues. We argue that this oversimplification results from the fact that the research on accounting and performance management has not identified and analyzed the elements of performance dialogue and, thus, the diverse set of choices arising from these elements has remained unnoticed (cf. Rajala et al., 2018).

This paper considers what managerial choices are used in the organizational design of dialogic performance management. Here, dialogic performance management refers to performance management that utilizes performance dialogues. Our approach is justified because the previous literature and practitioners have added performance dialogues to the agenda of performance management and therefore these dialogues have become a management issue that public managers try to organize with their choices. Managerial choices here means that managers select from a wide range of viable options the type of performance dialogues that are useful to the performance management agenda. We believe that only after explicating these choices can one start to examine the relationship between managerial choices and dialogic performance management successes. We think it would be beneficial to understand the how managers contribute with their choices to the successes or failures of dialogic performance management. 
To understand the managerial choices related to dialogic performance management, one needs more knowledge about performance dialogues than the current accounting and performance management research can provide. Because performance dialogue relies on dialogue, our literature review examines the general elements of a dialogue. To overcome the preconceptions regarding what constitutes a dialogue (cf. Isaacs, 2001a; Bebbington et al., 2007), we look at and synthetize the diverse conceptions of dialogue from different research streams to create a new conceptual framework describing the unifying elements of dialogue. In our literature review, we use inductive inferences, moving from individual perceptions of dialogue presented by different scholars to the general perception of dialogue and its common elements. This general perception is our theoretical conclusion and conceptualization, and it is based on the similarities we found among different descriptions of dialogue. Therefore, it should be taken as a proposition for future research, which requires more testing. After identifying the common elements of dialogues, we explain why performance dialogue is a special kind of a dialogue. This completes our conceptual framework describing the elements of performance dialogue. At the end of the theoretical section, we also propose a definition of dialogic performance management that is based upon the concepts of performance dialogue and performance management.

In the empirical part of the paper, we test whether or not dialogic performance management involves managerial choices that shape the actual dialogue. Inductive reasoning and narrative analysis are used in this section. Our empirical data are gathered from a Finnish local government using multiple methods. We show the set of managerial choices that were used in dialogic performance management. The findings on managerial choices make it evident how public managers use their power to shape the form of the performance dialogues. However, we feel that both public managers and academics need to have a better understanding of these choices so that they can discern different performance dialogue types, analyze their qualities, and start to find best dialogue practices. Our results help to study further the practice of dialogic performance management. For example, this study did not address which managerial choices were the most successful and which tended to lead to failed dialogues. Future research could and should address these questions if we want to learn more about relationships between managerial choices and dialogic performance management successes. For practitioners, mapping out the managerial choices offers opportunities to adjust performance management practices and, through these, the organizational performance.

The rest of this article is organized as follows. In the next section, a literature review addressing the elements of performance dialogue and a definition of dialogic performance management are presented. The third section presents the research method used in the empirical section of the study. The fourth section describes an empirical analysis of dialogic performance management in the local government under study. The fifth section connects the results of this research to discussions in previous literature.

\section{From dialogue to dialogic performance management}

As a term, dialogic performance management consists from the concepts of dialogue and performance management. Performance management has at least the following functions: target setting, employee directing, metrics development, performance information production via performance measurement, performance reporting, and performance information use. Of course, it expands the performance management functions if one acknowledges that performance information can be used for learning, 
controlling, communicating, budgeting, motivating, promoting/advocating, evaluating, celebrating, collaborating, contracting, sense-making, decision-making, account-giving, framing, reassuring, and preventing issues (Behn, 2003; Moynihan, 2009; Van Dooren and Van de Walle 2011).

Performance management in the public management context has been defined as "a system that generates performance information through strategic planning and performance measurement routines and that connects this information to decision venues, where the information is expected to influence a range of possible decisions" (Moynihan, 2008b: p.5). Measurement requires developing performance measures (Bourne et al., 2000). It is typical for performance management to use "performance information to affect programs, policies, or any other organization [sic] actions aimed at maximizing the benefits of public services" (Hatry, 2002: p. 352). Performance management also directs and supports "employees to work as effectively and efficiently as possible in line with the needs of the organization" (Walters, 1995).

Previously, there has been a strong focus on measurement and reporting in performance management literature (Radnor and Barnes, 2007). Recently, authors who write about public performance management have emphasized the use of performance information in the public sector. These authors have shifted their attention away from the technocratic measurement tradition toward interpretative and dialogic forms of performance management that focus on managerial actions and the use of performance information (Moynihan, 2005; Bititci et al., 2012; Agostino and Arnaboldi, 2015; Laihonen and Mäntylä, 2017). For example, Amaratunga and Baldry (2002) justifiably called for a change from performance measurement to more comprehensive performance management that utilizes measured results in decision-making. The ideal performance management system is interested in the use of performance information (Pollitt, 2006).

The literature on public performance management suggests that dialogue is becoming a part of performance management, but no one has clearly stated what separates the performance dialogue as a concept from the dialogue. To make this distinction, one has to first understand what is a dialogue. Here, we propose the idea that dialogue is a sum of its elements. To identify these elements, we looked for similarities between different descriptions of dialogue presented in accounting, performance management, dialogue, and dialogic leadership literature. Then, we defined these common elements based on the similarities we perceived and gave them names, as shown in the left column of Table 1. Based on our literature review, we argue that performance dialogue is a special kind of a dialogue because it has all six common elements of dialogue as well as one additional element: performance dialogue builds upon performance information (cf. Moynihan, 2008a; Rajala et al., 2018). By joining the concepts of performance dialogue and performance management, we propose an analytic definition of dialogic performance management:

Dialogic performance management (DPM) embeds performance dialogue into performance management to set objectives, direct employees, define metrics, produce performance information via measuring, and/or determine actions to improve performance.

Table 1. Common elements of a dialogue 


\begin{tabular}{|c|c|}
\hline $\begin{array}{l}\text { The common } \\
\text { element }\end{array}$ & How dialogue was described in the literature \\
\hline $\begin{array}{l}\text { A dialogue has } \\
\text { a purpose }\end{array}$ & $\begin{array}{l}\text { Dialogue produces a revelation of presence (Buber, 1958), expresses verbally authentic } \\
\text { human life (Bakhtin, 1984), provides continuous critique of language (De Mare et al., } \\
\text { 1991), serves a purpose (Bohm, 1996; Yankelovich, 1999), seeks the truth (Apatow, } \\
\text { 1998), is intended to reach a new understanding (Isaacs, 2001b), offers learning } \\
\text { (Moynihan, 2005), aims at achieving a new understanding (Banathy and Jenlink, 2005), } \\
\text { develops democratic forms of social interaction (Brown and Dillard, 2015a), and } \\
\text { improves the dialogue between citizens and an administration while creating budget } \\
\text { allocations (Aleksandrov et al. 2018). }\end{array}$ \\
\hline $\begin{array}{l}\text { A dialogue has } \\
\text { a topic }\end{array}$ & $\begin{array}{l}\text { Dialogue concentrates on ways of relating to others (Buber, 1958), scrutinizes human } \\
\text { life (Bakhtin, 1984), examines hate (De Mare et al., 1991), settles into a theme (Bohm, } \\
\text { 1996), deals with an issue or question (Apatow, 1998), addresses issues (Yankelovich, } \\
\text { 1999;Isaacs, 2001b), focuses on organizational goals and knowledge about outcomes } \\
\text { (Moynihan, 2005), interprets culture, among other things (Banathy and Jenlink, 2005), } \\
\text { addresses accounting theory and practice (Brown and Dillard, 2015a), and considers } \\
\text { budget allocations (Aleksandrov et al., 2018). }\end{array}$ \\
\hline $\begin{array}{l}\text { le has } \\
\text { its }\end{array}$ & $\begin{array}{l}\text { Dialogue arises from relations between humans (Buber, 1958), refers to experiencing the } \\
\text { world with others (Bakhtin, 1984), is exercised by small and large groups of people (De } \\
\text { Mare et al., 1991), is built upon participants (Bohm, 1996), includes participants with } \\
\text { varying roles (Apatow, 1998; Yankelovich, 1999; Isaacs, 2001b), joins together a diverse } \\
\text { set of organizational actors (Moynihan, 2005), brings individuals together to share ideas } \\
\text { (Banathy and Jenlink, 2005), engages citizens (Brown and Dillard, 2015a), and can } \\
\text { involve administration officers, consultant-researchers, citizens, activists, and NGOs } \\
\text { (Aleksandrov et al. 2018). }\end{array}$ \\
\hline $\begin{array}{l}\text { A dialogue has } \\
\text { a time span }\end{array}$ & $\begin{array}{l}\text { Dialogue happens in the present, not in the past (Buber, 1958), occurs throughout a } \\
\text { person's life (Bakhtin, 1984), continues as long as it fails to handle hate among people } \\
\text { (De Mare et al., 1991), demands time (Bohm, 1996), happens in time (Apatow, 1998), } \\
\text { takes time (Yankelovich, 1999), calls for time (Isaacs, 2001b), is a routine event } \\
\text { (Moynihan, 2005), is used to communicate solutions in times of tragedy (Banathy and } \\
\text { Jenlink, 2005), is an ongoing process (Brown and Dillard, 2015a), and attaches to } \\
\text { budgeting timetable (Aleksandrov et al. 2018). }\end{array}$ \\
\hline $\begin{array}{l}\text { A dialogue has } \\
\text { a forum }\end{array}$ & $\begin{array}{l}\text { Dialogue is a system in which people meet (De Mare et al., 1991), takes place in arenas } \\
\text { (Bakhtia 1984), appears in meetings (Buber, 1958; Bohm, 1996; Isaacs, 2001b), occurs } \\
\text { in a space (Apatow, 1998), is a meeting (Yankelovich, 1999), is implemented in learning } \\
\text { forums (Moynihan, 2005), needs a common space (Banathy and Jenlink, 2005), happens } \\
\text { in spaces of engagement (Brown and Dillard, 2015a), and emerges in participatory } \\
\text { budgeting meeting (Aleksandrov et al. 2018). }\end{array}$ \\
\hline $\begin{array}{l}\text { A dialogue is } \\
\text { based upon a } \\
\text { dialogue } \\
\text { method (i.e., } \\
\text { code of } \\
\text { behavior) }\end{array}$ & $\begin{array}{l}\text { Dialogue relies on suspension (Buber, 1958), is based on responding, asking questions, } \\
\text { and agreeing (Bakhtin 1984), allows for different types of communication (De Mare et } \\
\text { al., 1991), entails voicing, listening, and suspending presumptions (Bohm, 1996), uses a } \\
\text { method of dialogue (Apatow, 1998), requires equality and listening with empathy as well } \\
\text { as bringing assumptions into the open (Yankelovich, 1999), necessitates certain practices } \\
\text { (Isaacs, 2001b), identifies, examines, and suspends assumptions (Moynihan, 2005), } \\
\text { utilizes knowledge sharing through language (Banathy and Jenlink, 2005), avoids } \\
\text { unidimensional assessments (Brown and Dillard, 2015a), and is based on the behavioral } \\
\text { guidelines provided by the moderator (Aleksandrov et al. 2018). }\end{array}$ \\
\hline
\end{tabular}


We argue that the existence of performance dialogue does not mean that dialogic performance management also exists. For example, citizens can engage in performance dialogue that does not serve any function of public sector performance management. If this is the case, then performance dialogue exists but this dialogue does not create dialogic performance management. However, if performance dialogue does function as a part of public sector performance management, then this dialogue creates dialogic performance management. In its simplest form, even individual performance dialogue generates dialogic performance management if it is used to conduct a certain performance management function, such as target-setting or performancereporting. However, dialogic performance management can also build upon a series of performance dialogues that conduct different performance management functions within an organization.

From the perspective of dialogic performance management, some of the descriptions in Table 1 could also be understood as managerial choices. For example, Moynihan's (2005) description of dialogue indicates that managers orchestrating dialogic performance management should choose learning as the purpose of performance dialogues if they seek to create a learning organization. Brown and Dillard (2015a) suggest that developing democratic forms of social interaction should be the purpose of dialogue when the goal is to create dialogic accounting (see Table 1). Thus, the information in Table 1 demonstrates that each element of performance dialogue involves choices. One can choose different purposes, topics, participants, time spans, forums, and dialogue methods. Consequently, in dialogic performance management, public managers make these choices that shape the elements of performance dialogue. Therefore, we use the elements of performance dialogue as a analytic framework when we will search from the empirical data what managerial choices are used in the organizational design of dialogic performance management.

\section{The research design}

\subsection{The organizational context}

We carried out our empirical study in a case organization that provides childcare services in the city of Turku, Finland. Their childcare consists of planned and goal-directed early childhood education and nurturing with an emphasis on pedagogy. In Finland, childcare is provided in public or private daycare centers, playschools, or facilities provided by registered private childminders. Our case organization was a line organization operating under the education and childcare committee in the local government. The line organization and its chain of command, which are described in Figure 1, involved the central administration, the education and childcare committee, the education and childcare management group, the childcare management team, the northern, southern, and private provision management groups, and the public daycare centers. The private daycare units were excluded from this research because we focused on a public sector line organization. The goals of the line organization were derived mainly from legislation and regulations, the local government's strategy, policy programs, government projects, and strategic and operational contracts; its budget was based on the local government's annual budget. 
In general, the movement towards dialogic performance management is a rather typical phenomenon in Finnish local government and goes hand in hand with participatory management initiatives. However, Turku put more effort into developing their dialogic performance management in 2013 when they started to create their new strategic management model. Their strategic management model required updating because Turku wanted to improve the implementation of their strategies. The connection between strategies and operative activities was seen as problematic because strategy did not guide service production enough. therefore the model development began. One of the key areas of development was to increase participatory management and create more interaction between the different levels of management and between the management and the employees. This model development emphasized the role of dialogic performance management.

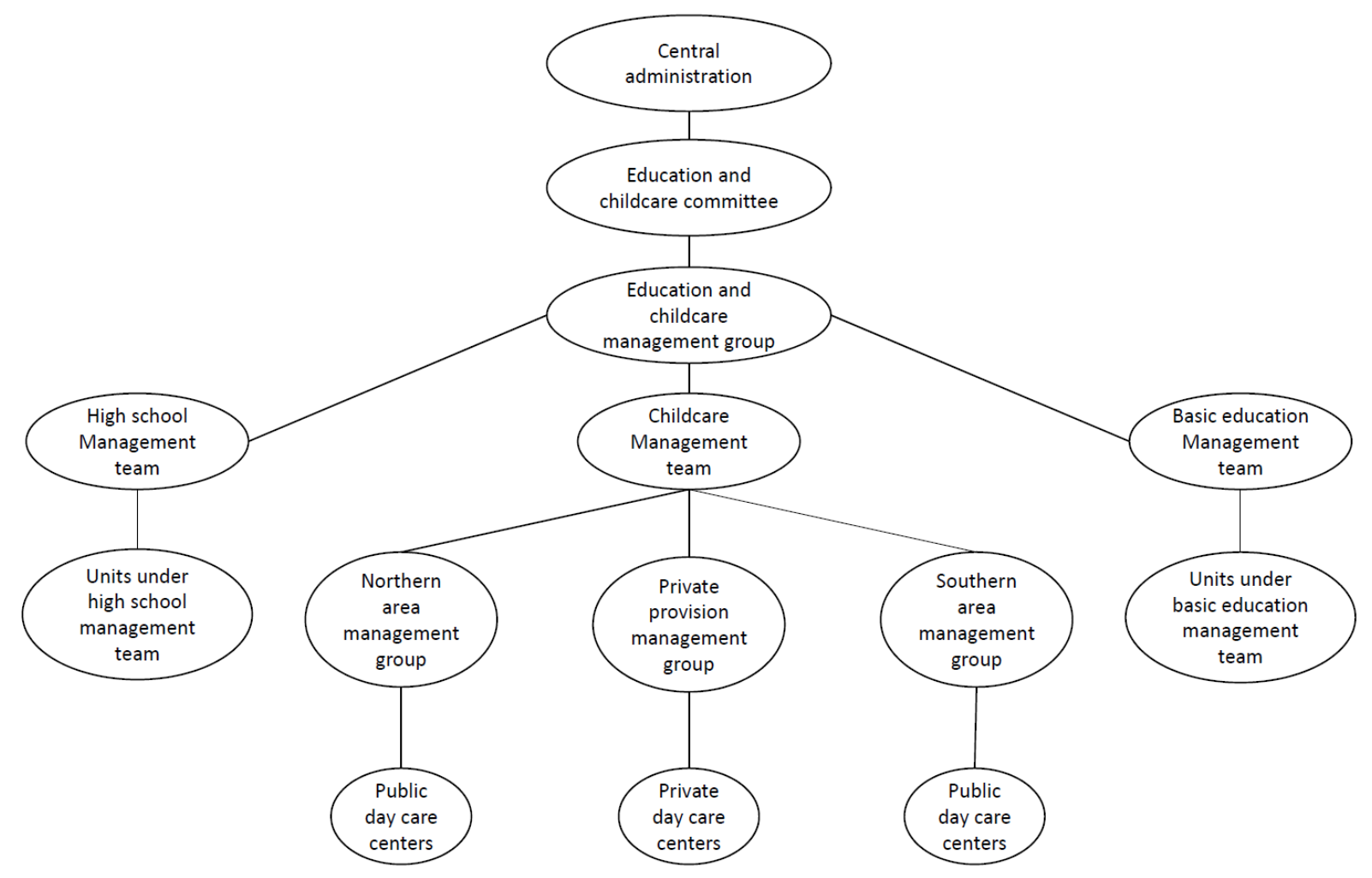

Figure 1. The line organization of Turku's child services from the top down

\subsection{The research method}

The research strategy used in this study was based on narrative research. The aim was to create a narrative of the managerial choices associated with dialogic performance management. Our narrative research was grounded in ontological relativism and epistemological constructionism (Smith, 2013). In this research, we treated the research subjects as collaborators, rather than informants who were being guided by the research agenda (Altork, 1998). We acknowledged the research context and sought to understand dialogic performance management by studying the meanings that research subjects assigned to them (Klein and Myers, 1999). These meanings were conveyed in stories (Moen, 2006). Thus, we accepted Fry's (2002) notion that stories can contain knowledge. Because we encountered many public managers and documents, in the spirit of constructionism, we created an aggregate of narratives, each of which had a bearing on the others. This aggregate of narratives 
provided an answer for our research question and described what dialogic performance management was. We interpreted the stories within the conceptual framework created in the literature review section. Therefore, the managerial choices described to us are viewed through the conceptual framework used in this study and reported accordingly; this method demonstrates that ontological relativism was present in this research.

In this study, we concentrated on two types of stories provided by the public managers. First, we examined stories about dialogic performance management to confirm that this type of management actually took place in the case organization. Second, we investigated what managerial choices dialogic performance management included in the case organization. The empirical data was gathered from multiple sources with various data collection methods (cf. Clandinin and Connelly, 2000). By using empirical data from internal and external documents (internal memos, minutes of meetings, organizational instructions, budgets, financial statements), interviews, self-reports, and workshop observations, we performed a triangulation to test whether different kinds of empirical data yielded contradictory findings. The narrative answering the research question was confirmed and its reliability was ensured in all five stages of the research using Huberman's (1995) and Webster and Mertova's (2007) criteria for reliability in narrative researches. Table 2 summarizes the empirical phases.

Table 2. Knowledge construction between the researchers and participants in the study.

\begin{tabular}{|c|c|c|}
\hline $\begin{array}{l}\text { Empirical phase and the } \\
\text { methods used }\end{array}$ & Participants & Main objectives of the phase \\
\hline $\begin{array}{l}\text { 1. Interview study in Fall } \\
\text { 2016. The interviews } \\
\text { were recorded, } \\
\text { transcribed, and coded. } \\
\text { The common elements } \\
\text { of dialogues were used } \\
\text { to form research } \\
\text { questions for the } \\
\text { interviews (see } \\
\text { Appendix 1). Interviews } \\
\text { lasted approximately an } \\
\text { hour and took place in } \\
\text { Turku. }\end{array}$ & $\begin{array}{l}\text { Eleven public managers from } \\
\text { Turku } \\
\text { Interviewees represented three } \\
\text { organizational levels: top } \\
\text { management (2), service area } \\
\text { management (5), and service unit } \\
\text { management (4). With these } \\
\text { interviews, we covered the central } \\
\text { administration ( } 2 \text { interviewees), } \\
\text { education and childcare committee } \\
\text { (all interviewees), education and } \\
\text { childcare management group (6 } \\
\text { interviewees), childcare } \\
\text { management team ( } 3 \text { interviewees), } \\
\text { northern (1 interviewee), southern } \\
\text { (1 interviewee), and private } \\
\text { provision (1 interviewee) } \\
\text { management groups, as well as the } \\
\text { public daycare centers (4 } \\
\text { interviewees who also participated } \\
\text { to either northern or southern } \\
\text { management groups). }\end{array}$ & 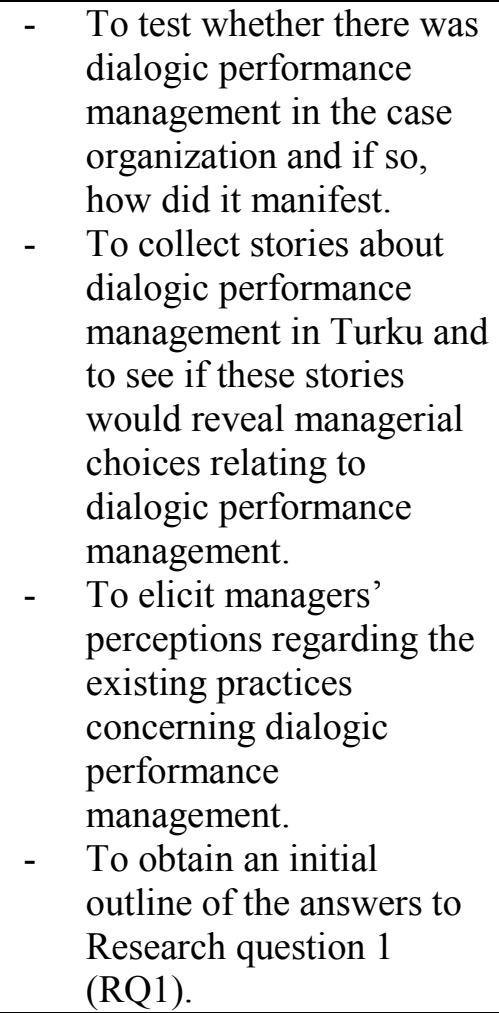 \\
\hline $\begin{array}{l}\text { 2. Self-reporting and } \\
\text { observations in a joint } \\
\text { development workshop } \\
\text { in Tampere with }\end{array}$ & $\begin{array}{l}\text { - Ten participants representing three } \\
\text { local governments in Finland. } \\
\text { There were two public managers } \\
\text { from the central administration of }\end{array}$ & $\begin{array}{l}\text { To present and discuss } \\
\text { the main findings of the } \\
\text { interview study } \\
\text { conducted in phase } 1 .\end{array}$ \\
\hline
\end{tabular}




\begin{tabular}{|c|c|c|}
\hline $\begin{array}{l}\text { participants from three } \\
\text { local governments on } \\
10 \text { March } 2017 \text {. The } \\
\text { workshop lasted } 6 \\
\text { hours. The participants } \\
\text { of the workshop self- } \\
\text { reported possible } \\
\text { improvements in their } \\
\text { dialogic performance } \\
\text { management practices. } \\
\text { Observation notes from } \\
\text { managerial choices and } \\
\text { dialogic performance } \\
\text { management were } \\
\text { made. }\end{array}$ & $\begin{array}{l}\text { Turku and neither one were } \\
\text { interviewed in phase one. }\end{array}$ & 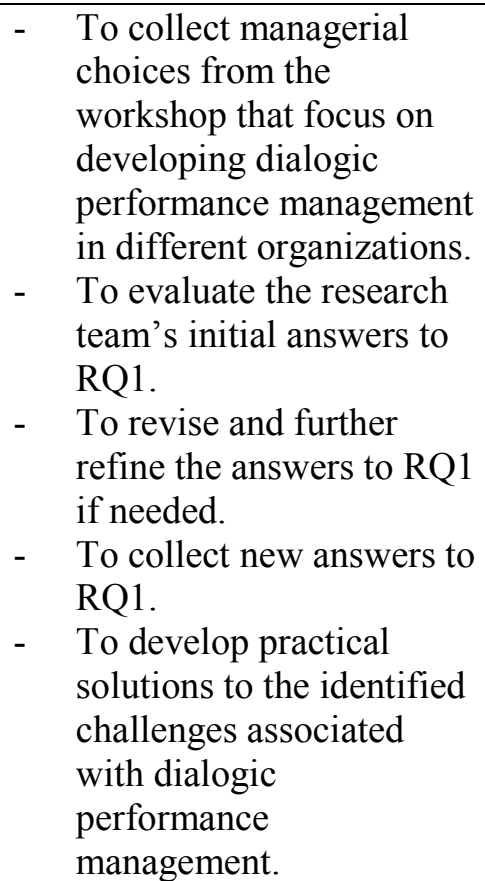 \\
\hline $\begin{array}{l}\text { 3. Interview study and } \\
\text { internal document } \\
\text { collection on } 3 \text { October } \\
\text { 2017. The interviews } \\
\text { were not recorded but } \\
\text { notes were taken during } \\
\text { them. The interviewer } \\
\text { used either a shared } \\
\text { screen or repetition to } \\
\text { check whether his notes } \\
\text { were correct and related } \\
\text { to important matters. } \\
\text { Interviews lasted } \\
\text { approximately an hour } \\
\text { and took place in Turku. }\end{array}$ & $\begin{array}{l}\text { Seven public managers from Turku } \\
\text { (four of these were not interviewed } \\
\text { in the first phase) } \\
\text { Interviewees represented three } \\
\text { organizational levels: top } \\
\text { management (5), service area } \\
\text { management (1), and service unit } \\
\text { management (1). With these } \\
\text { interviews, we covered the central } \\
\text { administration ( } 2 \text { interviewees), } \\
\text { education and childcare committee } \\
\text { (all interviewees), education and } \\
\text { childcare management group (4 } \\
\text { interviewees), childcare } \\
\text { management team ( } 2 \text { interviewees), } \\
\text { northern (1interviewee), southern } \\
\text { and private provision management } \\
\text { groups, as well as the public } \\
\text { daycare centers (1 interviewee). }\end{array}$ & $\begin{array}{l}\text { To assess the current } \\
\text { procedures of dialogic } \\
\text { performance management } \\
\text { and address the strategic } \\
\text { and operational contracts } \\
\text { in the city. } \\
\text { - To evaluate the research } \\
\text { team's answers to RQ1. } \\
\text { - To revise and refine the } \\
\text { answers to RQ1 if } \\
\text { needed. } \\
\text { To collect new answers to } \\
\text { RQ1. }\end{array}$ \\
\hline $\begin{array}{l}\text { 4. Self-reporting and } \\
\text { observations in city- } \\
\text { specific development } \\
\text { workshops in Turku on } \\
\text { 4 December 2017. The } \\
\text { workshops lasted } \\
\text { approximately three } \\
\text { hours. Participants' self- } \\
\text { reports included time- } \\
\text { based goal proposals for } \\
\text { childcare. These goal } \\
\text { proposals were topic }\end{array}$ & $\begin{array}{l}\text { Two workshops in Turku with eight } \\
\text { and ten participants (4 public } \\
\text { managers participated for the first } \\
\text { time to the study). } \\
\text { The city-specific workshops } \\
\text { focused on the service area level, } \\
\text { and participants included service } \\
\text { area managers from childcare } \\
\text { management group and childcare } \\
\text { management team and service unit } \\
\text { managers from daycare units. In } \\
\text { addition, two development } \\
\text { specialists from the city's }\end{array}$ & $\begin{array}{l}\text { To further analyze the } \\
\text { case-specific challenges } \\
\text { associated with dialogic } \\
\text { performance management } \\
\text { and address the strategic } \\
\text { and operational contracts } \\
\text { in the city. } \\
\text { - To develop solutions to } \\
\text { the case-specific } \\
\text { challenges. } \\
\text { To evaluate the revised } \\
\text { and developed answers to } \\
\text { RQ1. }\end{array}$ \\
\hline
\end{tabular}




\begin{tabular}{|c|c|c|}
\hline $\begin{array}{l}\text { suggestions for next } \\
\text { year's performance } \\
\text { dialogues. The field } \\
\text { notes concentrated on } \\
\text { the current form of } \\
\text { dialogic performance } \\
\text { management and its } \\
\text { background as } \\
\text { presented by the public } \\
\text { managers attending the } \\
\text { workshops. }\end{array}$ & $\begin{array}{l}\text { administration participated in the } \\
\text { dialogue so that we could have the } \\
\text { voice of the central administration } \\
\text { in the workshops. }\end{array}$ & $\begin{array}{l}\text { To evaluate the research } \\
\text { team's answers to RQ1. } \\
\text { - Collect new answers to } \\
\text { RQ1. }\end{array}$ \\
\hline $\begin{array}{l}\text { 5. Scrutiny of the research } \\
\text { team's case report on } \\
\text { the dialogic } \\
\text { performance } \\
\text { management in Turku } \\
\text { by the respondents from } \\
15 \text { October to } 5 \\
\text { December } 2017\end{array}$ & $\begin{array}{ll}- & \text { Two public managers from Turku }\end{array}$ & $\begin{array}{ll}\text { - } & \text { To evaluate the revised } \\
\text { and developed answers to } \\
\text { RQ1. } \\
\text { - To revise and further } \\
\text { develop the answers to } \\
\text { RQ1 if needed. } \\
\text { - To collect new answers to } \\
\text { RQ1. }\end{array}$ \\
\hline
\end{tabular}

\section{Dialogic performance management in practice}

\subsection{Managers' perceptions of dialogic performance management}

As stated in the narratives we encountered, a performance dialogue is an event in which managers and/or their subordinates jointly analyze performance information and discuss its meaning, while pinpointing the actions and inactions needed to improve the performance (Interviewee F). One of the interviewees described how the performance dialogues served their performance management purposes in the following way (Interviewee A):

The discussions are continuous... [In these discussions,] we monitor the number of customers... and how we can respond to the service needs in that region. We follow the service need and what actions we need to do to match this need.... We think about practical actions.... We use financial measures all the time... the development of service quality is being followed... We get customer feedback... population forecasts are available to us.... Our job is to take the information to the decision-making points.... [in these discussions,] Evaluation is regular and development is constant.

The above quotation and the other interviews confirmed that dialogic performance management did exist in our case organization. As shown in the quotation, public managers do use performance information when they collectively interpret and discuss organizational performance. Moreover, performance information is interpreted when public managers identify practical actions to enhance performance. Dialogic performance management was built upon a series of performance dialogues taking place within the organization. The following is an example (Interviewee F):

We have these discussions with decision-makers and this refers to the education and children committee. Then we have the education and management group. Then...there is childcare management team and going down further in the hierarchy we have the unit supervisors and the 
discussions with them.... The education and children committee is most concerned about the financial aspects... The education and management group is mostly interested in efficiency... service network and its development... quality of the service is left to the childcare management team.... The discussion are continuous. When one ends, another discussion starts.

Dialogic performance management was common in all management levels that we examined and public managers saw it as an important tool that supported the performance management functions and created more participatory management (e.g., interviewees D, E, and I and the observation notes). Of course, public managers also reported challenges of dialogic performance management and these are shown to some extent under the next heading in order to demonstrate that managerial choices do matter (e.g., Interviewee C). Next, we will empirically examine the managerial choices associated with dialogic performance management. These choices mold the common elements of performance dialogue and call for the managers' attention when there is a need to ensure that the dialogue process aligns with administrative timelines.

\subsection{The managerial choices affecting dialogic performance management}

The first managerial choice in dialogic performance management is the public manager's choice to orchestrate performance dialogue by determining its elements, such as the purpose, topic, participants, forums, time span, dialogue method, and performance information. If the public manager chooses not to shape the formation of performance dialogue, then it emerges independently. If he or she chooses to organize the performance dialogue, then another set of managerial choices arises. The rest of this section considers the managerial choices that shape how particular performance dialogues are structured.

In Turku performance dialogues served multiple purposes, including decision-making, sense-making, target-setting, problem-solving, improving, controlling, budgeting, reporting, evaluating, informing, learning, and innovating. According to the interviews and internal documents, the main purpose of a dialogue was typically chosen in advance. All public managers involved in the study stated that the managerial choice in determining the main purpose was heavily influenced by annual planning and monitoring routines (Interviewee H). Managers chose purposes that supported the planning and monitoring cycles of the organization (Interviewee J). Typically, performance dialogues were utilized to create a common understanding of the current performance development. Because the overall performance of the childcare service area was determined by the performance of various daycares, dialogic performance management was considered a useful tool for obtaining a holistic view of the performance of the service area. As one manager stated, "with dialogue, we can achieve common understanding on matters" (Interviewee A). Another manager added, "in regional meetings, where we go through these matters, we look at the situation of the whole region...for example, the results, such as the utilization rates and how many children we have had" (Interviewee C).

In the case organization, the assignment of topics was seen as a managerial choice because assigning different topics to different dialogues created a division of labor between the various performance dialogues. Thus, public managers set the topics for individual performance dialogues before they took place. This meant that, for example, every childcare management team meeting addressed the following seven topics: service area matters, the content and development of childcare services, personnel matters, financial matters, calendar-related topics, other issues, and general announcements 
(internal document 1). These topics left room for many kinds of matters to be addressed within the performance dialogue. However, performance information was not used for every topic. This meant that dialogic performance management, as defined in this article, did not always occur for all topics. Nevertheless, the interviewees recognized that performance dialogues took place in some sections of the meetings.

Our case analysis showed that, sometimes, public managers picked a topic from several alternatives by choosing the performance information to be used in a certain performance dialogue. If input information was used, then the dialogue typically focused on topics relating to inputs. Input measures not only indicated what aspects of performance were to be considered but also determined the unit of analysis. The different types of performance information that could be chosen included inputs, processes, outputs, outcomes, efficiency, and cost-effectiveness information (internal documents 2). The performance information could be both qualitative and quantitative (Interviewee A). Sometimes, public managers thought that the focus was placed on the wrong type of information, which frustrated members of the organization because more important issues were given little attention (Interviewee D). Managers also often assigned different types of performance information to different people in a performance dialogue, creating a division of labor between the participants.

Another managerial choice to be made in dialogic performance management was which participants to include in the dialogue. For example, public managers chose the participants who were expected to attend all the management team meetings, thus forming the management team (internal document 1). This choice was meant to achieve a holistic view of the performance of the service area (interview notes from the second round of interviews). Public managers also brought in visiting participants to introduce additional information into the dialogue and to contribute an in-depth view of a certain topic. As one public manager put it, "if some special area is in the focus, we will bring experts of that area to the conversations" (interview B). Thus, visiting participants expanded the shared understanding of the regular participants. It required managerial skill to identify when visiting participants served the purpose of the dialogue and when they did not.

By recognizing the organizational positions of the individuals involved in the dialogues and by distinguishing between members and non-members of the organization, it was possible to determine different types of performance dialogues, from which the managers chose the ones to fit their managerial needs. We identified internal, external, and boundary-crossing performance dialogues in our case organization. In internal performance dialogues, the participants were public sector actors (Interviewee A). External dialogues took place outside the public sector (e.g., external stakeholders discussed the public sector's performance). Cross-boundary (inter-organizational) performance dialogues involved private, public, and non-profit organizations in which the citizens may have a role (Interviewee $\mathrm{F}$ ).

According to our interviewees, internal, external, and cross-boundary performance dialogues could be vertical, horizontal, or diagonal. Vertical performance dialogues were common in administrative sectors and in line organizations. They involved participants from different hierarchical levels within a single organization (Interviewee F). In their simplest form, vertical performance dialogues took place between a manager and his or her immediate subordinate (e.g., a yearly performance review) or between strategic and operative actors. There were four types of horizontal performance dialogues (Interviewee A): cross-sector, cross-unit, cross-team, and co-worker. In all four types of dialogues, 
the participants were peers, and no participant outranked the others in the organizational hierarchy (e.g., Interviewee C).

In cross-sectoral performance dialogues, the participants were from different administrative sectors (e.g., two participants from healthcare sector and three participants from education and childcare sector). A cross-unit performance dialogue took place when the participants represented different units in the same administrative sector (i.e., both were in the education and childcare sector but in different daycare units in the city of Turku) (Interviewee A). Cross-team performance dialogues involve situations in which teams within the same daycare unit have a dialogue. A co-worker performance dialogue took place between members of the same team within a certain daycare unit (Interviewee C). A diagonal performance dialogue is a hybrid form that combines elements of vertical and horizontal performance dialogues. In diagonal performance dialogues, the participants were from different administrative sectors or units and different hierarchical levels (Interviewee A). As evidenced by the above descriptions, choosing the internal and external forms of performance dialogues that are most beneficial to the organization was very complicated. The large size of the organization (over 12,000 employees) also contributed to complications. The complicated nature of the organization often inhibited vertical, diagonal, and cross-sectional performance dialogues.

Because there are many types of organizational actors in the public sector, performance dialogues included participants from a variety of occupations. It was often the public manager's job to choose the occupations to be included. When we examined the interview data, we identified several types of professions and roles played by the participants. For example, participants included politicians, citizens, public officials, or executive officers of private or non-profit organizations (Interviewee F). When public managers chose the participants of the performance dialogue, they chose between cross-professional, political, managerial, and politico-managerial performance dialogues. Each of these dialogues offered advantages and disadvantages that made the choice more difficult (interview notes as well as Interviewees $\mathrm{G}$ and $\mathrm{H}$ ).

Every performance dialogue had a time span (Interviewee K), which public managers often chose. In our case study, we identified a managerial choice between recurring, non-recurring, and single performance dialogues. The interview data included several examples in which recurring dialogues, such as half-yearly reviews and budget dialogues, were used in the local government (internal document 3). Public managers often chose non-recurring performance dialogues when the results of projects were assessed. Single performance dialogues happened only once when the public manager faced emergent and urgent issues. The managers also faced another time-related choice over whether or not it would be sensible to organize performance dialogues in a synchronous or asynchronous fashion. A synchronous dialogue occurs in real time whereas asynchronous dialogue does not occur at the same time and users can send messages and respond to them with considerable time gaps. Synchronous dialogues were favored on many occasions because they were easier to follow and people were more familiar with them (Interviewee J). However, there seemed to be a digitalization agenda to achieve more asynchronous performance dialogues (Interviewee E). Thus, there was some tension over the choice between synchronous and asynchronous performance dialogues.

From the empirical data, we identified another choice that defined the time span. This choice dealt with duration, which refers to the amount of time consumed by the performance dialogue. It was often difficult to determine how much time could or should be dedicated to a certain dialogue. According 
to the narratives, it seemed that this question was one of the most crucial determinants of dialogic performance management, because a lack of time often impeded the dialogue. Indeed, all the performance information could not be assessed and analyzed adequately in short meetings (Interview G). Setting an excessively tight timeframe for a performance dialogue often meant that the performance dialogue turned into managerial monologue. If there was no time to conduct a dialogue, the public manager merely described the performance information and what decisions and actions it required while the other participants remained silent. A limited amount of time also meant that not every topic worth pursuing could be addressed and not everyone could participate in the dialogues. Excess time was not beneficial either; when performance dialogues were given too much time, the participants were, to some extent, de-motivated to participate because they had tight schedules and little spare time to dedicate to inefficient meetings.

In addition to time span, choosing an appropriate forum for the performance dialogue was a crucial aspect of managerial decisions. Managers had to choose between virtual or physical forums, formal or informal forums, and personal or open forums (Interviewee C). Virtual forums referred to platforms on the Internet or Intranet, whereas physical forums were face-to-face meetings. Informal forums were coffee-room and corridor dialogues about performance, and formal forums were official meetings. Open forums were accessible to all who wanted to participate, and personal forums required a personal invitation to participate. Selecting an unsuitable forum impaired the effectiveness of the performance dialogues, whereas an appropriate forum significantly enhanced the dialogue. For instance, some interviewees indicated that too many virtual forums were used for the dialogues. One interviewee pointed this out by describing performance dialogues in emails: "long emails serve no purpose and we should give these up" (Interviewee J).

One important part of dialogic performance management was to get people to share their thoughts regarding the performance information and possible actions that this information necessitated. To achieve this, public managers chose the dialogue method. The managers also instructed and reminded participants about this method. The highest-ranking public manager often had the most important role in creating an environment in which people engaged in the dialogue and shared their perceptions (interview notes from phase three and interview session three). Choosing the right dialogue method required a contextual understanding of how to build a successful performance dialogue event when different participants wanted to learn, innovate, and share knowledge about several different topics. Occasionally, the chosen dialogue method failed and the performance dialogue failed consequently (Interviewee C).

\section{Discussion and conclusion}

The aim of this paper was to answer the following research question: what are the managerial choices related to the organizational design of dialogic performance management. We used narrative research to answer this question. The chosen research question takes into consideration two aspects. First, dialogue is a useful tool or method that can be an integral part of successful performance management (Brown, 2009; Moynihan, 2005; 2008a; Laihonen and Mäntylä, 2017; Rajala et al., 2018). Indeed, the public managers participating in this research named dialogue as an important tool that supported performance management functions and created more participatory management at all levels of management. Second, the previous literature has painted an oversimplified picture of these 
managerial choices because they have not identified the elements of performance dialogues and the diverse set of managerial choices arising from these elements.

Previous studies have demonstrated some of the managerial choices related to dialogic performance management by providing descriptions of dialogues. However, they tend to ignore many types of dialogue arising from various managerial choices because these studies were not designed to map out the different kinds of performance dialogues (e.g., Moynihan 2008a; Brown 2009; Brown and Dillard, 2015ab; Aleksandrov et al. 2018). The problem is that these other types of dialogue have remained hidden. For example, little is known about recurring and boundary-crossing outcome dialogues that operate in virtual spaces. Recognizing different performance dialogues opens up possibilities to investigate how these dialogues function in an organization. Our research revealed a variety of unexplored performance dialogues resulting from different managerial choices.

To get a broader perspective on the variety of performance dialogues, we examined managerial choices relating to seven key elements of performance dialogue. We empirically demonstrated that public managers can choose different purposes, topics, participants, time spans, forums, dialogue methods, and performance information. Each of the seven elements involved several options from which the public manager made his or her choice. Some of the options were discussed in the analysis section of this paper. The set of options we identified is not complete, but it provides an answer to our research question by presenting an outlook on the variety of options relating to performance dialogues. The options we found demonstrated that various types of performance dialogues were seen as useful in the case organization. In addition to these seven elements, public managers made also choices concerning the divisions of labor among the participants. The divisions of labor determined who was responsible for monitoring certain performance information.

Implementing dialogic performance management means that performance dialogues become management issues and managerial choices addressing these dialogues have to be made. For example, the inevitable choice from which public managers cannot escape is whether to determine the elements of a performance dialogue. If the public manager chooses not to interfere with the formation of the performance dialogue, then he or she lets the performance dialogue emerge independently. Public managers can also choose to determine some or all the elements of a certain performance dialogue that they want to orchestrate.

The variety of managerial choices we found in this study shows that one should be careful about oversimplifying the managerial choices used to orchestrate dialogic performance management. Oversimplification can narrow down the options relating to the managerial choices if it creates overly simplistic mental frameworks for public managers and academics. This oversimplification can have adverse effects in both research and practice if it inhibits one's ability to see other possible performance dialogues that may work better.

Our study makes it evident that past studies describing performance dialogues are actually presenting a selection of choices (c.f., Moynihan, 2005; 2008; De Bruijn and Van Helden, 2006; Brown, 2009; Laihonen and Mäntylä, 2017). With the elements of performance dialogue identified in this research, one can assess what these choices are and which elements of dialogue are determined by these choices. These choices also reveal how one attempts to govern the performance dialogue. Performance dialogues can be harnessed to serve different purposes and the ability to direct the performance dialogues and their results can have both negative and positive outcomes to the society 
as demonstrated in the previous research (Moynihan, 2008; Brown, 2009). Thus, the managerial choices we examined do represent the use of manager's power.

In addition to describing the managerial choices related to dialogic performance management, the study also proposed a definition of dialogic performance management, which we needed to answer our research question. Dialogic performance management as a concept can be used in empirical and theoretical studies to advance our current knowledge of its applications. Future studies could explore, for example, how managerial choices are constructed in practice. This could be done by using theories from psychology (c.f., Aleksandrov et al. 2018).

We concede that our analysis has some weaknesses. It is possible that conceptual framework we adopted made us blind to some important aspects of dialogic performance management. This problem arises whenever researcher utilizes conceptual framework for research purposes. One should also keep in mind that a case study limits the generalizability of our findings. However, we argue that our findings can operate as testable propositions for future research. In addition, we believe that our approach is appropriate as an explorative analysis of an under-examined phenomenon. We are also aware that narrative analysis differs from the mainstream tradition of performance management studies, but this approach was able to provide answers to our research question.

Based on the previous literature and the results of this study, we argue that academics have not addressed how different managerial choices that shape performance dialogues are able to create the benefits identified in previous literature; in particular, how do these choices affect pluralism, equality, empowerment, learning, efficiency, effectiveness, innovation, participation, transparency, and governance within an organization (cf. Brown, 2009; Brown and Dillard, 2015a; Moynihan, 2005)? The managerial choices identified in this study create different types of performance dialogues in an organization, and it is currently unclear which type of performance dialogues create the benefits mentioned above, and which do not. It is also unknown which types of performance dialogue make political elites stronger (cf. Celerier and Botey, 2015; Kuruppu et al., 2016) or create pseudo-participation (Uddin et al., 2011), and which do not. Rajala et al. (2018) have studied the challenges of performance dialogues, but they have not considered how managerial choices create challenges for these dialogues. Overall, many unanswered research questions remain when one compares our research results to the previous literature. Thus, our results have paved the way for future studies examining the different forms of dialogic performance management and their benefits to organizations.

\section{References}

Aleksandrov, E., Bourmistrov, A., \& Grossi, G. (2018). "Participatory budgeting as a form of dialogic

accounting in Russia: actors' institutional work and reflexivity trap". Accounting, Auditing \& Accountability Journal, Vol. 31 No. 4, 1098-1123.

Altork, K. (1998), "You never know when you want to be a redhead in Belize”, in DeMarris, K. (Ed.), Inside Stories: Qualitative Research Reflections, Lawrence Erlbaum, Mahwah, NJ, pp. 111-125.

Agostino, D. and Arnaboldi, M. (2015), "The new public management in hybrid settings: new challenges for performance measures", International Review of Public Administration, Vol. 20 No. 4, pp. 353-369. 
Amaratunga, D. and Baldry, D. (2002), "Moving from performance measurement to performance management", Facilities, Vol. 20 No. 5/6, pp. 217-223.

Apatow, R. (1998), The Spiritual Art of Dialogue: Mastering Communication for Personal Growth, Relationships, and the Workplace, Inner Traditions, Rochester, NY.

Baiocchi, G. and Ganuza, E. (2014), "Participatory budgeting as if emancipation mattered", Politics \& Society, Vol. 42 No. 1, pp. 29-50.

Bakhtin, M. (1984), "Problems of Dostoevsky's poetics", in Emerson, C. (Ed.), University of Minnesota

Press, MN.Banathy, B.H. and Jenlink, P.M. (Eds.) (2005), Dialogue as a Means of Collective Communication, Kluwer Academic/Plenum Publishers, New York, NY.

Bebbington, J., Brown, J., Frame, B. and Thomson, I. (2007), “Theorizing engagement: the potential of a critical dialogic approach", Accounting, Auditing and Accountability Journal, Vol. 20 No. 3, pp. 356-381.

Behn, R. 2003. Why Measure Performance? Different Purposes Require Different Measures. Public Administration Review 63 (5): 586-606.

Bititci, U., Garengo, P., Dörfler, V. and Nudurupati, S. (2012), "Performance measurement: challenges for tomorrow", International Journal of Management Reviews, Vol. 14 No. 3, pp. 305327.

Bourne, M., Mills, J., Wilcox, M., Neely, A. and Platts, K. (2000), "Designing, implementing, and updating performance measurement systems", International Journal of Operations \& Production Management, Vol. 20 No. 7, pp. 754-771.

Bohm, D. (1996), “On dialogue”, in Nichol, L. (Ed.), Routledge, New York, NY.

Buber, M. (1958), I and Thou, Collier-Macmillan, New York, NY.

Brown, J. (2009), "Democracy, sustainability and dialogic accounting technologies: taking pluralism seriously", Critical Perspectives on Accounting, Vol. 20 No. 3, pp. 313-342.

Brown, J. and Dillard, J. (2015a), "Opening accounting to critical scrutiny: towards dialogic accounting for policy analysis and democracy", Journal of Comparative Policy Analysis, Vol. 17 No. 3, pp. 247-268.

Brown, J. and Dillard, J. (2015b), "Dialogic accountings for stakeholders: on opening up and closing down participatory governance”, Journal of Management Studies, Vol. 52 No. 7, pp. 961-985.

Célérier, L. and Botey, L.E. (2015), "Participatory budgeting at a community level in Porto Alegre: a Bourdieusian interpretation", Accounting, Auditing \& Accountability Journal, Vol. 28 No. 5, pp. 739-772.

Clandinin, D.J. and Connelly, F.M. (2000), Narrative Inquiry: Experience and Story in Qualitative Research, Jossey-Bass Publishers, San Francisco, CA.

De Bruijn, H. and Van Helden, G.J. (2006), "A plea for dialogue driven performance-based management systems: evidence from the Dutch public sector", Financial Accountability \& Management, Vol. 22 No. 4, pp. 405-423. 
de Mare, P., Piper, R. and Thompson, S. (1991), Koinonia: From Hate, Through Dialogue, to Culture in the Large Group, Karnac, London, UK.

Fry, R.E. (2002), Appreciative Inquiry and Organizational Transformation: Reports from the Field, Quorum Books, Westport, CN.

Harun, H., Van-Peursem, K. and Eggleton, I.R.C. (2015), "Indonesian public sector accounting

reforms: Dialogic aspirations a step too far?", Accounting, Auditing \& Accountability Journal, Vol. 28 No. 5, pp. 706-738.

Hatry, H.P. (2002), "Performance measurement: Fashions and fallacies", Public Performance \& Management Review, Vol. 25 No. 4, pp. 352-358.

Huberman, M. (1995), "Working with life-history narratives", in McEwan, H. and Egan, K. (Eds.) Narrative in Teaching, Learning, and Research, Teachers College Press (pp. 126-165), New York, NY.

Isaacs, W.N. (2001a), "Toward an action theory of dialogue", International Journal of Public Administration, Vol. 24 No. 7-8, pp. 709-748.

Isaacs, W. (2001b), Dialogue and the Art of Thinking Together, Crown Business, London, UK.

Klein, H. and Myers, M. (1999), "A set of principles for conducting and evaluating interpretive field studies in information systems", MIS Quarterly, Vol. 23 No. 1, pp. 67-94.

Kuruppu, C., Adhikari, P., Gunarathna, V., Ambalangodage, D., Perera, P. and Karunarathna, C. (2016), "Participatory budgeting in a Sri Lankan urban council: a practice of power and domination", Critical Perspectives on Accounting, Vol. 41, December, pp. 1-17.

Laihonen, H. and Mäntylä, S. (2017), "Principles of performance dialogue in public administration”, International Journal of Public Sector Management, Vol. 30 No. 5, pp. 1-16.

Lyons, E. and Coyle, A. (2016), Analysing Qualitative Data in Psychology, SAGE Publications Ltd., London.

Moen, T. (2006), "Reflections on the narrative research approach", International Journal of Qualitative Methods, Vol. 5 No. 4, pp. 56-69.

Moynihan, D.P. (2005), "Goal-based learning and the future of performance management", Public Administration Review, Vol. 65 No. 2, pp. 203-216.

Moynihan, D.P. (2008a), The Dynamics of Performance Management: Constructing Information and Reform, Georgetown University Press, Washington, D.C.

Moynihan, D. (2008b), “Advocacy and learning: an interactive-dialogue approach to performance information use," in Van Dooren, W. and Van de Walle, S. (Eds.), Performance Information in the Public Sector: How it is Used, Palgrave Macmillan, Basingstoke, UK, pp. 24-41

Moynihan, D. 2009. Through a Glass, Darkly: Understanding the Effects of Performance Regimes. Public Performance \& Management Review 32 (4): 592-603.

Pollitt, C. (2006), "Performance information for democracy: the missing link?", Evaluation, Vol. 12 No. 1, pp. 38-55. 
Radnor, Z.J. and Barnes, D. (2007), "Historical analysis of performance measurement and management in operations management", International Journal of Productivity and Performance Management, Vol. 56 No. 5, pp. 384-396.

Rajala. T., Laihonen, H. and Haapala, P. (2018), "Why are performance dialogues challenging in local governments?", Measuring Business Excellence. Vol. 22 Issue: 2, pp.117-129, https://doi.org/10.1108/MBE-06-2017-0032

Smith, B. (2013), “Disability, sport, and men's narratives of health: a qualitative study”, Health Psychology, Vol. 32, pp. 110-119.

Uddin, S., Gumb, B. and Kasumba, S. (2011), "Trying to operationalise typologies of the spectacle", Accounting, Auditing \& Accountability Journal, Vol. 24 No. 3, pp. 288-314.

Vakkuri, J. (2010), "Struggling with ambiguity: Public managers as users of NPM-oriented management instruments", Public Administration, Vol. 88, No. 4, pp. 999-1024.

Van Dooren W and Van de Walle S (eds) (2011) Performance Information in the Public Sector: How it is Used. Basingstoke: Palgrave Macmillan

Walters, M. (1995), The Performance Management Handbook, Institute of Personnel and Development, London, UK.

Webster, L. and Mertova, P. (2007), Using Narrative Inquiry as a Research Method: An Introduction to Using Critical Event Narrative Analysis in Research on Learning and Teaching, Routledge, New York, NY..

Yankelovich, D. (1999), The Magic of Dialogue: Transforming Conflict into Cooperation, Simon \& Schuster, New York, NY.

\section{Appendix 1 Interview questions}

\section{Managers' perceptions of dialogic performance management}

\section{Purpose and topic}

1. How would you describe discussions about performance?

2. For what purposes do you use performance information?

\section{Performance information}

3. What kind of information do you use when setting goals and choosing performance indicators (or when evaluating performance)?

- Are there problems related to performance information?

\section{Participants, forums, and time span}

4. Who participates in the definition of organizational goals and performance indicators?

- Are all the necessary participants present? Why or why not? 
5. When, where, and in what forums are conversations/discussions about goals and performance conducted?

\section{Dialogue method}

6. Are different interpretations/views of the performance information typically available?

7. Do listening, voicing of the thoughts, suspending the assumptions, respecting others and equality among the participants occur?

8. Are there conflicts, and if so, how do you resolve them?

\section{Impacts of the dialogue}

9. Do discussions about performance lead to development? Is the performance dialogue effective?

\section{Appendix 2}

\section{Empirical data in phase one}

Interviewee A

Interviewee B

Interviewee $\mathrm{C}$

Interviewee D

Interviewee $\mathrm{E}$

Interviewee $\mathrm{F}$

Interviewee $\mathrm{G}$

Interviewee $\mathrm{H}$

Interviewee I

Interviewee J

Interviewee $\mathrm{K}$

External document 1 (budget document)

External document 2 (financial statement)

\section{Empirical data in phase two}


Observation notes from empirical phase 2

Self-reports from empirical phase 2

\section{Empirical data in phase three}

Internal document 1 (minutes of meetings)

Internal document 2 (management instructions)

Internal document 3 (timetables for strategic negotiations and budget proposals)

Interview notes from session 1

Interview notes from session 2

Interview notes from session 3

Interview notes from session 4

Interview notes from session 5

\section{Empirical data in phase four}

Observation notes from empirical phase 4

Self-reports from empirical phase 4

\section{Empirical data in phase five}

Comments on the case report from public manager 1

Comments on the case report from public manager 2 